\title{
Enhancing Biosorption Characteristics of Marine Green Algae (Ulva lactuca) for Heavy Metals Removal by Alkaline Treatment
}

Laura Bulgariu ${ }^{1 *}$ and Dumitru Bulgariu行

${ }^{1}$ Technical University Gheorghe Asachi of laşi, Faculty of Chemical Engineering and Environmental Protection, Department of Environmental Engineering and Management, D. Mangeron Street, 71A, 700050-laşi, Romania

${ }^{2}$ Alexandru loan Cuza University of laşi, Faculty of Geography and Geology, Department of Geology, Carol I Street, no. 20A, 700506-laşi, Romania ${ }^{3}$ Romanian Academy, Filial of laşi, Collective of Geography, Carol I Street, no. 18, 700506-laşi, Romania

\begin{abstract}
The biosorption characteristics of alkaline treated marine green algae (Ulva lactuca) have been studied for the removal of $\mathrm{Pb}(\mathrm{II})$, $\mathrm{Zn}(\mathrm{II})$ and $\mathrm{Co}$ (II) from aqueous solution, at room temperature. Batch experiments were performed to examine the effect of $\mathrm{NaOH}$ concentration used for treatment, initial heavy metals concentration and contact time, in comparison with untreated algae. The biosorption capacity of alkaline treated marine green algae increases with increasing of $\mathrm{NaOH}$ concentration, up to 0.6 mol $\mathrm{L}^{-1}$, when an improvement of biosorption capacity with $11.75 \%$ for $\mathrm{Pb}(\mathrm{II}), 60.64 \%$ for $\mathrm{Zn}$ (II) and $62.53 \%$ for Co(II) respectively, was obtained. The Langmuir model provides best correlation of equilibrium experimental data, and the pseudo-second order describes well the biosorption kinetics of considered heavy metals. The heavy metal ions could be easily desorbed from loaded biosorbent, and this may be reuse at least in three biosorption/desorption cycles.
\end{abstract}

Keywords: Heavy metals; Alkaline treatment; Marine green algae (Ulva lactuca); Biosorption

\section{Introduction}

Industrial activities often produce wastewater containing large amounts of heavy metals that are discharged into environment, and that become an important source of pollution. Due to their toxicity, mobility and accumulation tendency, the contamination of aqueous environments with heavy metals is an important issue with serious ecological and human health consequences $[1,2]$. Therefore, it is desirable to eliminate the heavy metals from industrial wastewaters, and this could be also important from economical considerations [3]. Among heavy metals, $\mathrm{Pb}$ (II), $\mathrm{Zn}$ (II) and $\mathrm{Co}$ (II) are the most common contaminants of wastewater, due to their varied uses in different industrial activities, and have priority for removal from aqueous waste stream [4].

Conventional methods for heavy metals removal from wastewater include chemical precipitation, membrane filtration, adsorption on activated carbon and biological techniques [5-9]. Unfortunately, many of these methods are limited because are expensive, or have some disadvantages such as low selectivity, moderate removal yields, high energy consumption or generates large amounts of sludge, that are also difficult to treat [10].

Biosorption provide potential alternative to overcome the disadvantages of conventional methods for wastewater treatment containing heavy metals. Different materials of biologic origin, such as fungi, bacteria, yeasts, moss, aquatic plants, algae, etc. [10-13], can be efficient used for heavy metals removal from aqueous solution, due to their low-cost and minimization of secondary wastes [3].

Marine green algae could be especially useful as they are fairly abundant in many regions of the world, have a greatly metal removal potential and large surface area $[14,15]$. The metal binding capacity of marine green algae is determined by the presence of various functional groups of polysaccharides, proteins and lipids on the cell wall surface [16], but also by the small and uniform distribution of binding sites [17].

Nevertheless, there are still many aspects that need to be solved before that the marine green algae to be used in real applications in wastewater treatment. The most important of these are: (i) the biosorption capacity of marine green algae should be improved, mainly because low biosorption capacity may cause large amounts of wastes loaded with heavy metals [18], and (ii) minimization of secondary pollution, which is determined by the dissolution of organic compounds from biomass, during of biosorption process [19]. According to the studies from literature, the biosorption capacities of marine green algae for different heavy metals varied from 0.01 to $1.9 \mathrm{mmol} \mathrm{g}^{-1}$, which is significant lower that those obtained for commercial adsorbents, such as activated carbon. In consequence, a new preparation methods of biosorbents derived from marine green algae should be developed.

In order to improve the biosorption characteristics of marine green algae (Ulva lactuca) for heavy metals, a simple alkaline treatment was used as a preparation method of biosorbent. This treatment implied the mixing of marine green algae with well known concentration of $\mathrm{NaOH}$ solution, and the main advantage of this procedure is that the enhancement of biosorption characteristics of marine green algae is done without using expensive additives, and thus the cost of biosorbent preparation remains low.

In this study, the biosorption characteristics of alkaline treated marine green algae have been investigated for the removal of $\mathrm{Pb}(\mathrm{II})$, $\mathrm{Zn}$ (II) and $\mathrm{Co}$ (II) ions from aqueous solution, at laboratory scale. The effect of $\mathrm{NaOH}$ concentration used for alkaline treatment, initial heavy

*Corresponding author: Laura Bulgariu, Technical University Gheorghe Asachi of laşi, Faculty of Chemical Engineering and Environmental Protection, Department of Environmental Engineering and Management, $D$. Mangeron Street, 71A, 700050-Iaşi, Romania, Tel/Fax: 004-0232-271759; Email: Ibulg@ch.tuiasi.ro

Received December 10, 2013; Accepted January 15, 2014; Published January 22, 2014

Citation: Bulgariu L, Bulgariu D (2014) Enhancing Biosorption Characteristics of Marine Green Algae (Ulva lactuca) for Heavy Metals Removal by Alkaline Treatment. J Bioprocess Biotech 4: 146 doi: 10.4172/2155-9821.1000146

Copyright: (c) 2014 Bulgariu L, et al. This is an open-access article distributed under the terms of the Creative Commons Attribution License, which permits unrestricted use, distribution, and reproduction in any medium, provided the original author and source are credited. 
metals concentration and contact time was studied at room temperature $\left(22 \pm 0.5^{\circ} \mathrm{C}\right)$ in batch experiments, in comparison with untreated marine green algae. Three isotherm models (Langmuir, Freundlich and Dubinin-Radushkevich) and three kinetic models (pseudo-first order, pseudo-second order and intra-particle diffusion model) were used for the mathematical description of single component biosorption on untreated and alkaline treated marine green algae, and various models parameters have been calculated in each case.

\section{Experimental}

\section{Preparation of biosorbents}

The marine green algae (Ulva lactuca) were collected from Romanian Black Sea coast, during of summer (July-August, 2009). Before use, the raw marine green algae were washed several times with double distilled water, to remove impurities, dried in air at $70^{\circ} \mathrm{C}$ for 10 hours, and the grounded and sieved until the granulation reach less that 1.0-1.5 $\mathrm{mm}$. The obtained biomass was stored in desiccators for further use. The chemical composition and some physical-chemical properties of this biomass have been presented in a previous study [20].

The alkaline treatment was done by mixing the marine green algae samples with aqueous solutions of $\mathrm{NaOH}$. Thus, $5.0 \mathrm{~g}$ of algae biomass was mechanically shaken for 1 hour with $100 \mathrm{~mL}$ of $\mathrm{NaOH}$ solution, with known concentration (range from 0.2 to $1.0 \mathrm{~mol} \mathrm{~L}^{-1}$ ). After 24 hour of stand-by, the alkaline treated marine green algae samples were filtrated, washed with double distilled water until a neutral $\mathrm{pH}$, dried in air and then mortared.

\section{Reagents}

All chemical reagents were of analytical degree and were used without further purifications. In all experiments, double distilled water, obtained from a commercially distillation system, was utilized for the preparation and dilution of solutions.

The stock solution of heavy metals ( $\mathrm{Pb}(\mathrm{II}), \mathrm{Zn}$ (II) and $\mathrm{Co}(\mathrm{II})$, respectively), containing $10^{-2} \mathrm{~mol} \mathrm{M}(\mathrm{II}) \mathrm{L}^{-1}$ were prepared by dissolving metal nitrate salts (purchased from Aldrich) in double distilled water. Fresh dilution were prepared and used for each experiment. The initial $\mathrm{pH}$ value of working solutions was obtained using $10^{-3} \mathrm{~mol} \mathrm{~L}^{-1} \mathrm{HNO}_{3}$ solution.

\section{Biosorption experiments}

The biosorption experiments were performed for a single component, by batch technique at room temperature $\left(22 \pm 0.5^{\circ} \mathrm{C}\right)$, mixing samples of $0.2 \mathrm{~g}$ of untreated and alkaline treated marine green algae with $25 \mathrm{~mL}$ solution of known heavy metal concentration $(0.20$ $\left.3.39 \mathrm{mmol} \mathrm{L}^{-1}\right)$, in $150 \mathrm{~mL}$ conical flasks, with intermittent stirring. All experiments were run in duplicate, in optimum experimental conditions ( $\mathrm{pH}=5.0$, biosorbent dose $=8.0 \mathrm{~g} \mathrm{~L}^{-1}$ ), establish previously. For kinetics experiments a constant amount of untreated and alkaline treated marine green algae of $8.0 \mathrm{~g} \mathrm{~L}^{-1}$ was mixed with $25 \mathrm{~mL}$ of $0.85 \mathrm{mmol} \mathrm{L}^{-1}$ heavy metals solution, at various time intervals, between 5 and $180 \mathrm{~min}$. At the end of biosorption procedure, the solid and liquid phases were separated by filtration, and the heavy metals concentration in filtrate was determined spectrophotometrically (Digital Spectrophotometer S $104 \mathrm{D}, 1 \mathrm{~cm}$ glass cell) [21], using a prepared calibration graph.

The feasibility of alkaline treated marine green algae was assessed using desorption experiments, performed with $0.1 \mathrm{~mol} \mathrm{~L}^{-1} \mathrm{HCl}$ solution, by batch technique. The heavy metals-loaded biosorbent was washed with double distilled water and dried in air. The obtained samples $(1.0 \mathrm{~g})$ were treated with $10 \mathrm{~mL}$ of $0.1 \mathrm{mmol} \mathrm{L}^{-1} \mathrm{HCl}$ solution. Each sample was intermittently stirred for 2 hours, then filtrated and the concentration of heavy metals in filtrate was determined. The described procedure was repeated for three cycles, using the same biosorbent sample.

\section{FT-IR spectra measurements}

The FT-IR spectra of untreated and alkaline treated marine green algae were recorded with a Bio-Rad FT-IR Spectrometer, in a 400-4000 $\mathrm{cm}^{-1}$ spectral domain, $4 \mathrm{~cm}^{-1}$ resolution and 32 scans, by $\mathrm{KBr}$ pellet technique. The analysis of FT-IR spectra was carried out by examining the spectral bands that are modified.

\section{Data evaluation}

The biosorption efficiency of marine green algae, before and after alkaline treatment, for studied heavy metals was quantitatively evaluated from experimental results, with a relative standard deviation less than $\pm 0.5 \%$, using:

(a) amount of heavy metals retained by mass unit of biosorbent ( $q$, $\left.\mathrm{mmol} \mathrm{g}{ }^{-1}\right)$, calculated from the mass balance expression:

$$
q=\frac{\left(c_{0}-c\right) \cdot(V / 1000)}{m}
$$

(b) percent of heavy metals removal $(\mathrm{R}, \%)$, that can be obtained from:

$$
\mathrm{R}, \%=\frac{c_{0}-c}{c_{0}} \cdot 100
$$

where: $c_{0}$ is the initial concentration of heavy metals solution ( $\mathrm{mmol}$ $\left.\mathrm{L}^{-1}\right) ; c$ is the equilibrium concentration of heavy metals solution ( $\mathrm{mmol}$ $\left.\mathrm{L}^{-1}\right) ; V$ is the volume of solution $(\mathrm{mL})$ and $m$ is the biosorbent mass $(\mathrm{g})$.

The difference between the biosorption capacity of untreated and alkaline treated marine green algae was calculated according to expression [22]:

$$
\Delta q_{e}=\frac{q_{e, \text { treated }}-q_{e, \text { untreated }}}{q_{e, \text { untreated }}} \cdot 100
$$

where: $q_{e^{\prime}}$ treated $q_{e, \text { antreated }} q_{e^{\prime}}$ untreated are the amounts of heavy metals retained on mass unit of alkaline treated and untreated marine green algae respectively, $\left(\mathrm{mmol} \mathrm{L}^{-1}\right)$.

The desorption efficiency (Desorption,\%) was evaluated using the bellow mathematical equation [16]:

$$
\text { Desorption, } \%=\frac{q_{\text {desorbed }}}{q_{\text {retained }}} \cdot 100
$$

where: $q_{\text {desorbed }}$ is the amount of heavy metals desorbed on mass unit of biosorbent $\left(\mathrm{mmol} \mathrm{g}^{-1}\right) ; q_{\text {retained }}$ is the amount of heavy metals retained on mass unit of biosorbent $\left(\mathrm{mmol} \mathrm{g}^{-1}\right)$.

\section{Results and discussion}

\section{Effect of $\mathrm{NaOH}$ concentration used for alkaline treatment}

The effect of $\mathrm{NaOH}$ concentration used for alkaline treatment of marine green algae, for the biosorption of $\mathrm{Pb}(\mathrm{II}), \mathrm{Zn}(\mathrm{II})$ and $\mathrm{Co}(\mathrm{II})$ ions is presented in Figure 1. The obtained results indicate that the alkaline treatment improves the biosorption capacity of marine green algae for all studied heavy metals, in comparison with untreated biomass $\left(\mathrm{cNaOH}=0.0 \mathrm{~mol} \mathrm{~L}^{-1}\right)$.

In addition, the amounts of heavy metals retained on mass unit of biosorbent $\left(\mathrm{q}, \mathrm{mmol} \mathrm{g}^{-1}\right)$ increases with increasing of $\mathrm{NaOH}$ concentration up to $0.6 \mathrm{~mol} \mathrm{~L}^{-1}$, after that remains almost constant. This means that a $\mathrm{NaOH}$ concentration of $0.6 \mathrm{~mol} \mathrm{~L}^{-1}$ is sufficient for 
the efficient alkaline treatment of marine green algae, and this value of $\mathrm{NaOH}$ concentration was used for the preparation of alkaline treated marine green algae required in the further experiments. The enhancing of biosorption capacity obtained under these conditions $\left(\Delta \mathrm{q}_{\mathrm{e}}\right)$ was $6.36 \%$ for $\mathrm{Pb}(\mathrm{II}), 34.50 \%$ for $\mathrm{Zn}(\mathrm{II})$ and $40.60 \%$ for $\mathrm{Co}(\mathrm{II})$ respectively, in comparison with untreated biomass.

Generally, the alkaline treatment enhances the biosorption characteristics of biological materials, mainly due to the hydrolysis reactions [23,24]. The hydrolysis reaction can lead to the formation of more carboxylic $(-\mathrm{COOH})$ and hydroxyl groups $(-\mathrm{OH})$, both in undissociated and dissociated forms, that improve the metal-binding properties of algae biomass [25].

FT-IR spectra (Figure 2) of untreated and alkaline treated marine green algae were used to characterize the biosorbents. Several important peaks, corresponding to the essential functional groups of the algae cell wall are observed in the spectra of untreated marine green algae (spectra 1).

The broad and strong band from $3296 \mathrm{~cm}^{-1}$ is attributed to the overlapping of $\mathrm{O}-\mathrm{H}$ and $\mathrm{N}-\mathrm{H}$ stretching vibrations. Peak at 2939-2908 $\mathrm{cm}^{-1}$ correspond to carboxylic/phenolic vibrations. The peaks at 1535 $\mathrm{cm}^{-1}$ and $1417 \mathrm{~cm}^{-1}$ can be attributed to the $\mathrm{HO}$ - bonds of quinine, and the peak of $1656 \mathrm{~cm}^{-1}$ to the $\mathrm{C}=\mathrm{N}$ and $\mathrm{C}=\mathrm{O}$ stretching. The peaks at 1338 $\mathrm{cm}^{-1}, 1055 \mathrm{~cm}^{-1}$ and $1031 \mathrm{~cm}^{-1}$ can be assigned to $\mathrm{N}-\mathrm{H}$ bond, $-\mathrm{CH} 3$ release and $\mathrm{C}-\mathrm{OH}$ stretching vibrations, due to different functional groups on algae cell. The bands from $574 \mathrm{~cm}^{-1}$ and $464 \mathrm{~cm}^{-1}$ corresponds

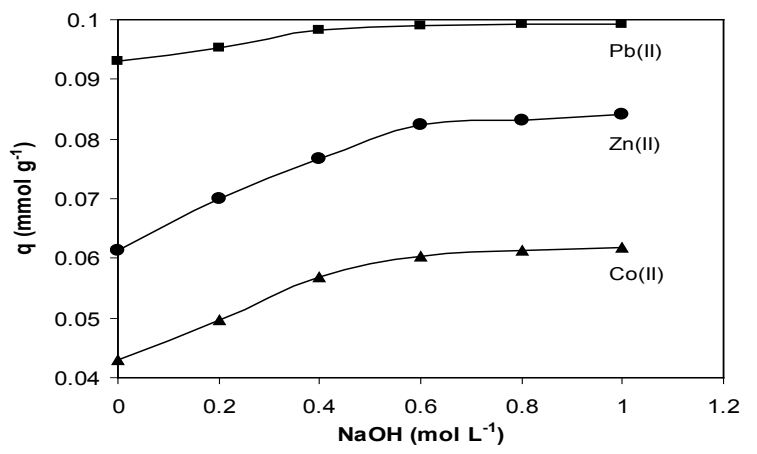

Figure 1: Effect of $\mathrm{NaOH}$ concentration used for alkaline treatment on the biosorption efficiency of studied heavy metals.

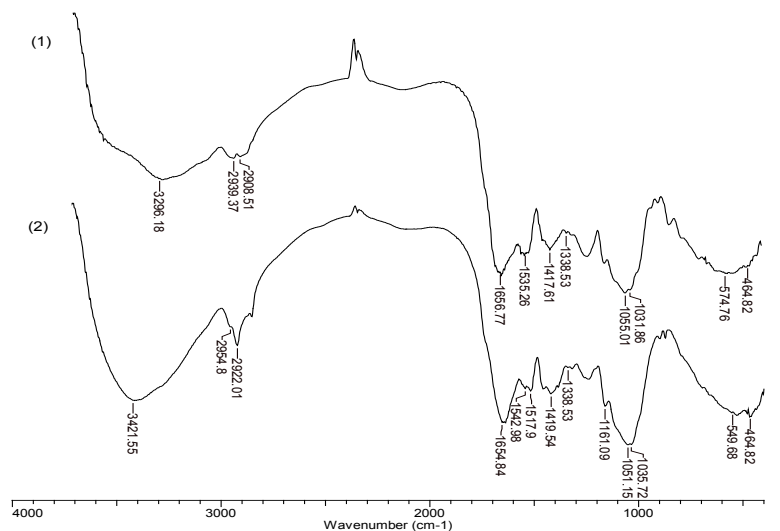

Figure 2: FT-IR spectra of untreated (1) and alkaline treated (2) marine green algae (Ulva lactuca). to the $\mathrm{C}-\mathrm{N}-\mathrm{S}$ shearing due to polypeptides structure of algae cells.

After alkaline treatment of marine green algae with $0.6 \mathrm{~mol} \mathrm{~L}^{-1}$ $\mathrm{NaOH}$ solution, the most significant modifications can be observed in case of absorption bands corresponding to carboxyl and hydroxyl groups (Figure 2 - spectra 2). Thus, the absorption bands from 3296 $\mathrm{cm}^{-1}, 1656 \mathrm{~cm}^{-1}$ and $1055^{-1} 031 \mathrm{~cm}^{-1}$ are shifted to $3421 \mathrm{~cm}^{-1}, 2954 \mathrm{~cm}^{-1}$, $1654 \mathrm{~cm}^{-1}$ and $1051^{-1} 035 \mathrm{~cm}^{-1}$, respectively. These modifications suggest that after alkaline treatment, the carboxyl and hydroxyl groups became more available for the interactions with heavy metals, without to be significant affected the chemical structure of marine green algae.

\section{Effect of initial heavy metals concentration}

It was previously showed [20] that the untreated marine green algae can be efficient use for the removal of heavy metal ions from aqueous solution, and that the maximum removal efficiency is obtained at initial solution $\mathrm{pH}$ of 5.0 and $8.0 \mathrm{~g} \mathrm{~L}^{-1}$ biomass dose. In order to compare the biosorption characteristics of untreated and alkaline treated marine green algae, the experimental conditions were maintained the same.

The effect of initial concentration of $\mathrm{Pb}$ (II), $\mathrm{Zn}$ (II) and $\mathrm{Co}$ (II) ions on the biosorption efficiency both on untreated and alkaline treated marine green algae, in optimum experimental conditions, was examined in the initial concentration range from 0.20 to $3.39 \mathrm{mmol}$ $\mathrm{M}(\mathrm{II}) \mathrm{L}^{-1}$, and the obtained results are illustrated in Figure 3.

An increase of the amounts of heavy metals retained on mass unit of biosorbent with increasing of initial concentration can be observed for both untreated and alkaline treated marine green algae. This variation is mainly determined by the increase of interaction probability between heavy metals and functional groups from biosorbent surface, with increasing of initial concentration of studied metal ions.

On the other hand in the studied concentration range, the alkaline treated marine green algae have better biosorptive characteristics than untreated marine green algae (Figure 3), for all heavy metals. This is more evident at high initial concentrations. Thus, for an initial concentration of $3.39 \mathrm{mmol} \mathrm{M}(\mathrm{II}) \mathrm{L}^{-1}$, the biosorption capacity is $0.3432 \mathrm{mmol} \mathrm{g}^{-1}$ for $\mathrm{Pb}(\mathrm{II}), 0.2086 \mathrm{mmol} \mathrm{g}^{-1}$ for $\mathrm{Zn}$ (II) and $0.1177 \mathrm{mmol} \mathrm{g}^{-1} \mathrm{Co}$ (II) respectively in case of untreated marine green algae, while in case of alkaline treated marine green algae the obtained values of biosorption capacities were $0.3835 \mathrm{mmol} \mathrm{g}^{-1}$ for $\mathrm{Pb}$ (II), $0.3352 \mathrm{mmol} \mathrm{g}$ - 1 for $\mathrm{Zn}$ (II) and $0.1913 \mathrm{mmol} \mathrm{g}^{-1}$ for $\mathrm{Co}(\mathrm{II})$, respectively. These differences are mainly determined by changing the availability of functional superficial groups after alkaline treatment. When marine green algae are treated with alkaline solution, the hydrolysis processes occur, and these will transform inactive superficial groups into available functional groups for interaction with heavy metals, and so the biosorption capacity increase greatly. The change of availability of superficial functional groups by this simple chemical treatment determine the increase of the biosorption capacity with $11.75 \%$ for $\mathrm{Pb}(\mathrm{II}), 60.64 \%$ for $\mathrm{Zn}$ (II) and $62.53 \%$ for $\mathrm{Co}(\mathrm{II})$ respectively, and thus the economical feasibility of this biosorbent was increased.

In addition, the oxidability index $\left(\mathrm{CCO}, \mathrm{mg} \mathrm{O}_{2} \mathrm{~L}^{-1}\right)$, which is a measure of the total content of organic compounds from certain aqueous solution, determined according with the standard procedure [26], decrease from $117.3 \mathrm{mg} \mathrm{O}_{2} \mathrm{~L}^{-1}$ in case of aqueous solution separated on untreated marine green algae, to $85.04 \mathrm{mg} \mathrm{O}_{2} \mathrm{~L}^{-1}$ in case of aqueous solution separated on alkaline treated marine green algae. The decrease of this parameter indicates that after alkaline treatment the dissolution of organic compounds from biomass during of biosorption process is significantly reduced, and so the secondary pollution is 

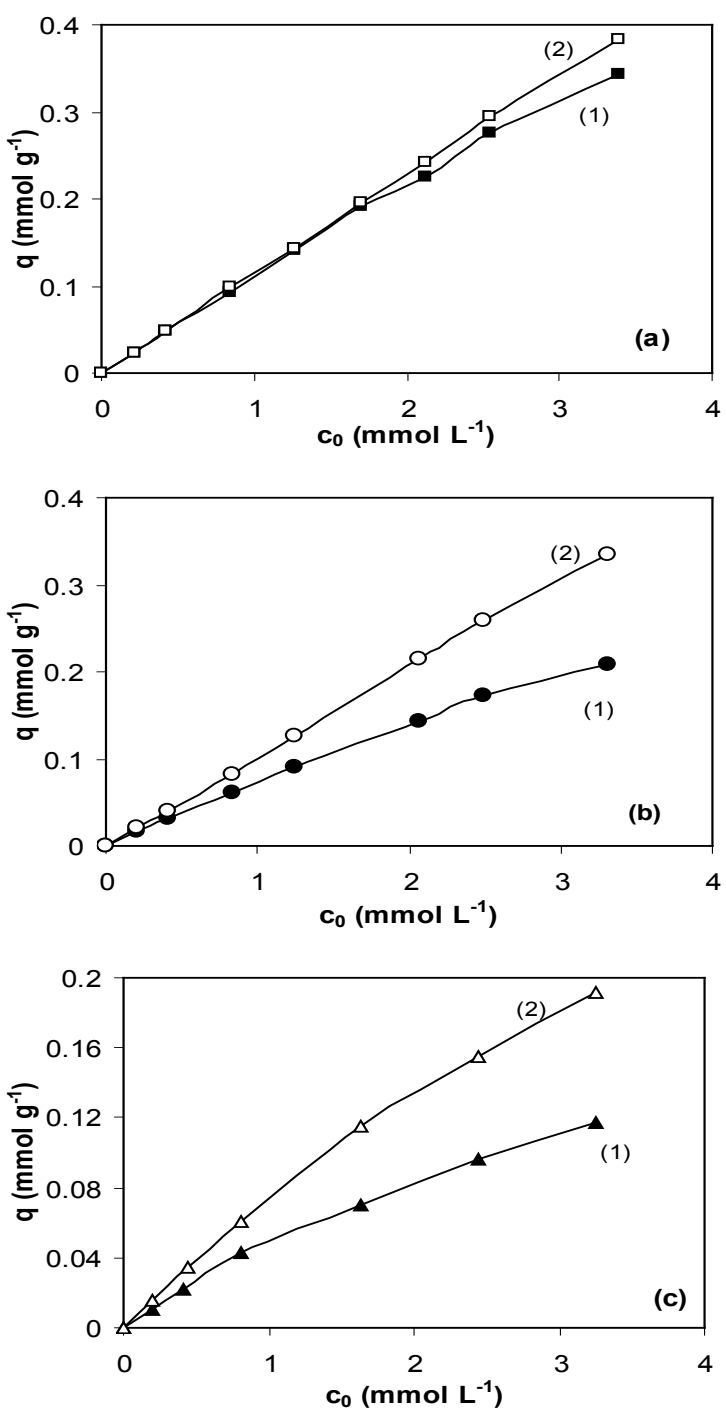

Figure 3: Effect of initial heavy metals concentration on their removal onto untreated (1) and alkaline treated (2) marine green algae: (a) $\mathrm{Pb}(\mathrm{II})$; (b) $\mathrm{Zn}(\mathrm{II})$ (c) $\mathrm{Co}(\mathrm{II})\left(\mathrm{pH}=5.0 ; 8 \mathrm{~g}\right.$ biosorbent $\mathrm{L}^{-1}$, temperature $=22^{\circ} \mathrm{C}$; contact time $=24$ hours).

minimized. This can be also another advantage of the use of alkaline treated marine green algae as biosorbent for the removal of heavy metals from wastewaters.

\section{Equilibrium modelling}

The analysis of equilibrium data by fitting them to different isotherm models is important to asses the practical biosorption capacity and optimization of the biosorption system design. In this study, the experimental results were fitted using three isotherm models (Langmuir, Freundlich and Dubinin-Radushkevich), and the best fit isotherm model was selected based on the linear regression correlation coefficients.

The Langmuir isotherm model is probably the most widely applied isotherm model, which is based on the monolayer biosorption onto homogeneous surface $[3,27]$. This model assumed that the biosorption forces are similar to the forces in chemical interactions, and is used to estimate the maximum biosorption capacity $\left(\mathrm{q}_{\max }, \mathrm{mmol} \mathrm{g}^{-1}\right)$,
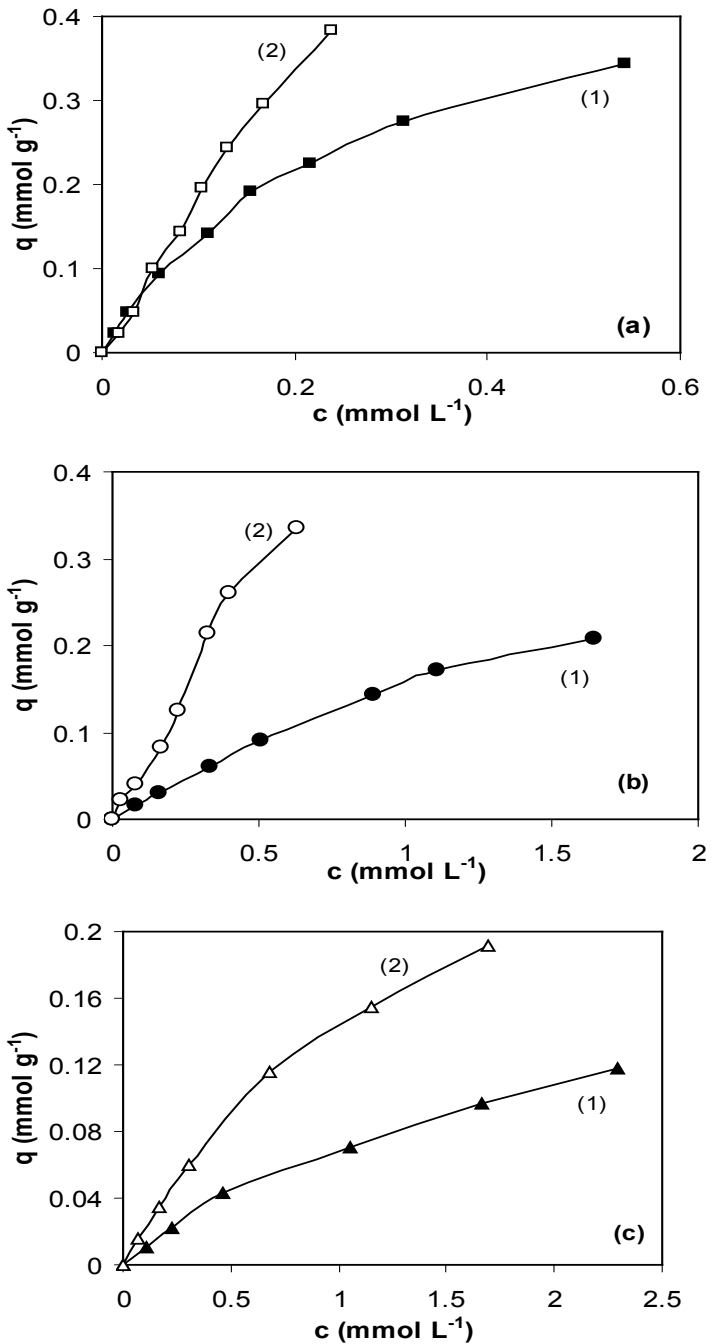

Figure 4: Biosorption isotherms of (a) $\mathrm{Pb}$ (II), (b) $\mathrm{Zn}$ (II) and (c) $\mathrm{Co}$ (II) respectively, onto untreated (1) and alkaline treated (2) marine green algae $\left(\mathrm{pH}=5.0 ; 8 \mathrm{~g}\right.$ biosorbent $\mathrm{L}^{-1}$, temperature $=22^{\circ} \mathrm{C}$; contact time $=24$ hours $)$.

corresponding to the biosorbent surface saturation. The linear form of Langmuir isotherm model is:

$$
\frac{1}{q}=\frac{1}{q_{\max }}+\frac{1}{q_{\max } \cdot K_{L}} \cdot \frac{1}{c}
$$

where: $\mathrm{q}_{\max }$ is the maximum biosorption capacity $\left(\mathrm{mmol} \mathrm{\textrm {g } ^ { - 1 }}\right)$, corresponding to the complete monolayer coverage of the surface, $\mathrm{c}$ is the concentration of heavy metals at equilibrium $\left(\mathrm{mmol} \mathrm{L}^{-1}\right)$ and $K_{L}$ is the Langmuir constant, related to the biosorption/desorption energy $\left(\mathrm{L} \mathrm{g}^{-1}\right)$

The essential feature of the Langmuir isotherm model can be expressed in terms of $R_{L}$, a dimensionless constant referred to as separation factor or equilibrium parameter, defined by the equation:

$$
R_{L}=\frac{1}{1+K_{L} \cdot c_{0}}
$$

where: $c_{0}$ is the highest initial concentration of heavy metals in aqueous solution $\left(\mathrm{mmol} \mathrm{L}^{-1}\right)$.

The value of RL indicate the type of isotherm, thus the biosorption process is irreversible when $R_{L}=0$, favourable when $0<R_{L}<1$, linear when 
$R_{L}=1$, or unfavourable when $R_{L}>1$.

The Freundlich isotherm model is derived from multilayer biosorption and biosorption on heterogeneous surface $[3,28]$, and was chosen to estimate the biosorption intensity of heavy metals on untreated and alkaline treated marine green algae. The linear form of this model is:

$$
\lg q=\lg K_{F}+\frac{1}{n} \lg c
$$

where: $K_{F}$ is the Freundlich constant and represent an indicator of biosorption capacity, $n$ is a constant that characterized the surface heterogeneity. The $1 / n$ value between 0 and 1 indicate that the biosorption process is favourable under studied conditions.

In order to appreciate the physical or chemical nature of the biosorption process, the equilibrium data were analyzed by DubininRadushkevich isotherm model [29,30], that is expressed by the following equation:

$$
\ln q=\ln q_{\max }^{D-R}-\beta \cdot \varepsilon^{2}
$$

where: is the maximum amount of heavy metals retained on mass unit of biosorbent $\left(\mathrm{mmol} \mathrm{g}^{-1}\right), \beta$ is a constant related to the biosorption energy $\left(\mathrm{mol}^{2} \mathrm{~kJ}^{-2}\right)$ and $\varepsilon$ is the Polanyi potential $(\varepsilon=\mathrm{RT} \ln (1+1 / \mathrm{c}))$, $\mathrm{R}$ is the gas constant $\left(\mathrm{kJ} \mathrm{mol}^{-1} \mathrm{~K}^{-1}\right), \mathrm{T}$ is the absolute temperature $(\mathrm{K})$ and $\mathrm{c}$ is the equilibrium concentration of heavy metals in solution $\left(\mathrm{mol} \mathrm{L}^{-1}\right)$.

The values of $\beta$ gives an idea about the mean free energy $\left(\mathrm{E}, \mathrm{kJ} \mathrm{mol}^{-1}\right)$ of biosorption, which can be calculated using the relation:

$$
\mathrm{E}=\frac{1}{\sqrt{-2 \beta}}
$$

If $\mathrm{E}$ value is between 8 and $16 \mathrm{~kJ} \mathrm{~mol}^{-1}$ the biosorption process follows by chemical ion exchange, while $\mathrm{E}<8 \mathrm{~kJ} \mathrm{~mol}^{-1}$ is characteristic of physical retention.

The biosorption isotherms of $\mathrm{Pb}(\mathrm{II}), \mathrm{Zn}(\mathrm{II})$ and $\mathrm{Co}(\mathrm{II})$ ions on untreated and alkaline treated marine green algae, used for the equilibrium modelling are illustrated in Figure 4, and the values of Langmuir, Freundlich and Dubinin-Radushkevich isotherm parameters, evaluated from the slope and intercept of corresponding linear dependencies, are summarized in Table 1.

The values of correlation coefficients $\left(\mathrm{R}^{2}\right)$ show that the biosorption isotherm data of studied heavy metals are very well represented by the Langmuir isotherm model and indicate the formation of monolayer coverage of heavy metal ions on the outer surface of biomass. The maximum biosorption capacity $\left(\mathrm{q}_{\mathrm{max}}, \mathrm{mmol} \mathrm{g}^{-1}\right)$, which is a measure to form a monolayer, calculated from Langmuir isotherm equation increases in the order $\mathrm{Zn}(\mathrm{II})>\mathrm{Pb}$ (II) $>\mathrm{Co}$ (II), which suggests that $\mathrm{Zn}$ (II) ions have higher affinity for the functional groups of the biosorbents, and can be largely retained.

On the other hand, it can also observe from Table 1 that the obtained values of maximum biosorption capacities were higher in case of alkaline treated marine green algae, than in case of untreated biomass. The increase of maximum biosorption capacities, calculated according with equation (3) was by $43.70 \%$ in case of $\mathrm{Pb}(\mathrm{II}), 37.40 \%$ in case of $\mathrm{Zn}$ (II) and $94.31 \%$ in case of $\mathrm{Co}(\mathrm{II})$, respectively. This is another argument which sustains the hypothesis that after alkaline treatment more many superficial functional groups become available for interaction with heavy metal ions. In consequence the amount of heavy metals required to form a complete monolayer on alkaline treated biomass surface is higher.

The calculated $\mathrm{R}_{\mathrm{L}}$ values range between 0 and 1 in all cases, indicating that the biosorption of $\mathrm{Pb}(\mathrm{II}), \mathrm{Zn}(\mathrm{II})$ and $\mathrm{Co}(\mathrm{II})$ ions from aqueous solution, both on untreated and alkaline treated marine green algae is a favourable process. The fractional values of $1 / \mathrm{n}$ from Freundlich isotherm model, suggests the heterogeneity of both biosorbents surface, and also indicate a favourable biosorption of $\mathrm{Pb}(\mathrm{II}), \mathrm{Zn}$ (II) and $\mathrm{Co}(\mathrm{II})$ ions on untreated and alkaline treated marine green algae.

Thehighervalues of $q_{\max }^{D-R}$ parameterfrom Dubinin-Radushkevich isotherm model (Table 1) than the experimental $q$ values obtained under optimized conditions indicate that both untreated and alkaline treated marine green algae have a porous structure. The obtained values of biosorption energy $\left(\mathrm{E}, \mathrm{kJ} \mathrm{mol}^{-1}\right)$ range between 11.45 and $14.12 \mathrm{~kJ} \mathrm{~mol}^{-1}$ and shows that biosorption is mainly a chemical process that occurs through electrostatic interactions, for all studied heavy metals, on untreated and alkaline treated marine green algae. A slightly decrease of the mean biosorption energy values can be observed in case of alkaline treated marine green algae, which is probably determined by the increment of the availability of functional groups from biosorbent surface for heavy metals biosorption.

\section{Effect of contact time}

Figure 5 shows the effect of contact time between biosorbents (untreated and alkaline treated marine green algae) and heavy metal ions from aqueous solution, under optimum experimental conditions.

It can be observed that the efficiency of biosorption process increases with increasing of contact time in each case. The biosorption process is very fast during the initial stage, when in the first $30 \mathrm{~min}$ around $80 \%$ of heavy metals $(79.88 \%$ for $\mathrm{Pb}(\mathrm{II}), 79.53 \%$ for $\mathrm{Zn}$ (II) and $78.90 \%$ for $\mathrm{Co}(\mathrm{II})$, respectively) are retained in case of untreated marine green algae, while in case of alkaline treated marine green algae in the first 5 min the removal percents were higher than $85 \%(88.92 \%$ for $\mathrm{Pb}(\mathrm{II}), 88.82 \%$ for $\mathrm{Zn}(\mathrm{II})$ and $85.19 \%$ for $\mathrm{Co}(\mathrm{II})$, respectively). After this fast initial step, the rate of biosorption process become slower near to equilibrium, which is practically obtained after $60 \mathrm{~min}$ in case of untreated biomass and $30 \mathrm{~min}$ in case of alkaline treated marine green algae, for all studied heavy metals.

The results presented above shows that in case of alkaline treated marine green algae, the required time for the biosorption process is significant lower. The very fast biosorption on alkaline treated marine green algae make this biosorbent more suitable for continuous flow rate treatment systems.

\section{Kinetics modelling}

The biosorption kinetics is significant in the design of wastewater treatment and allows the selection of optimum conditions for operating in full-scale batch process, as it provide valuable insights into the process pathways and mechanism of biosorption.

In order to investigate the biosorption kinetics of $\mathrm{Pb}(\mathrm{II}), \mathrm{Zn}$ (II) and $\mathrm{Co}(\mathrm{II})$ respectively on untreated and alkaline treated marine green algae, three kinetic models, namely pseudo-first order, pseudo-second order and intra-diffusion particle model, were used to analyze the experimental data.

The linear form of the pseudo-first order kinetic model [31,32] is given by the following relation:

$$
\lg \left(q_{e}-q_{t}\right)=\lg q_{t}-\frac{k_{1}}{2.303} \cdot t
$$

where: $q_{e}$ and $q_{t}$ are the amounts of heavy metals retained on mass unit of biosorbent $\left(\mathrm{mmol} \mathrm{g}^{-1}\right)$ at equilibrium and at time $\mathrm{t}$ respectively, and $k_{1}$ is the rate constant of pseudo-first order kinetic model $\left(\mathrm{min}^{-1}\right)$. 

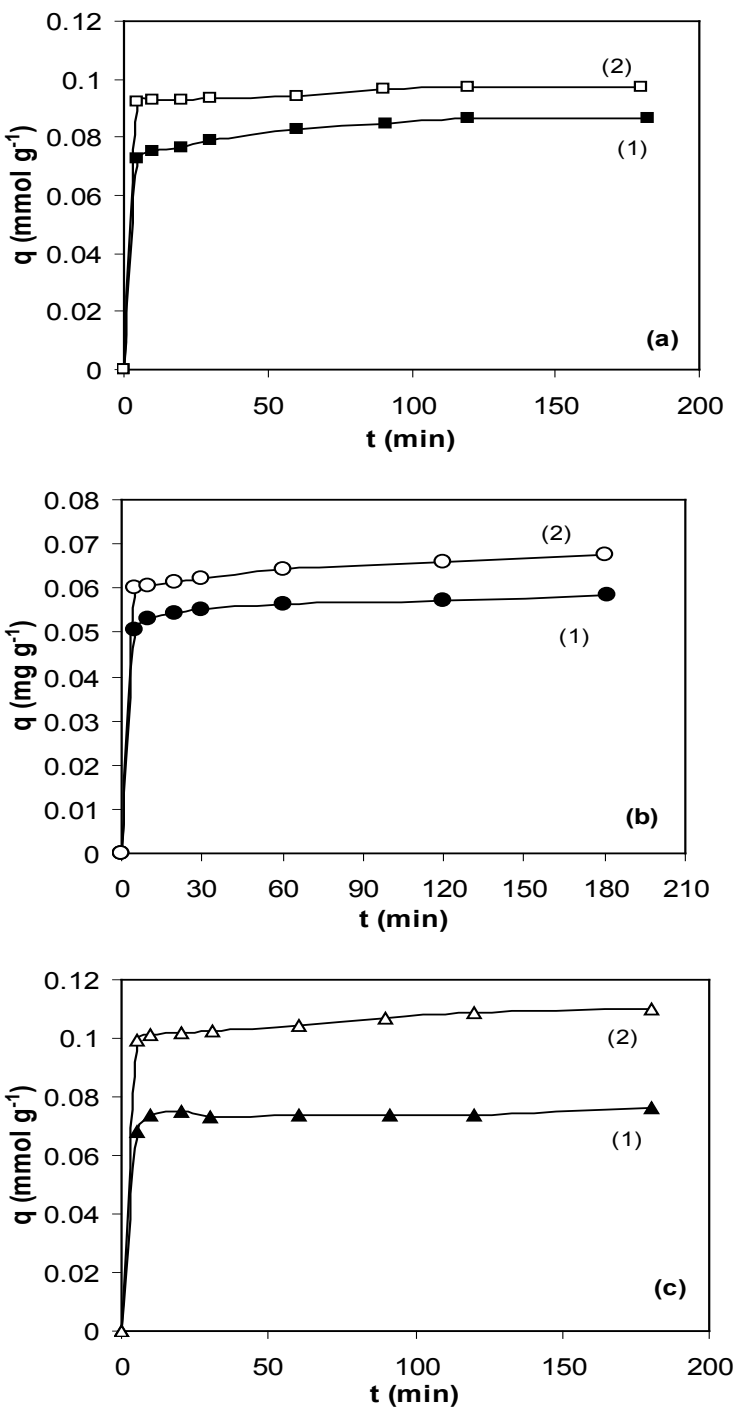

Figure 5: Effect of contact time on the heavy metals biosorption onto untreated (1) and alkaline treated (2) marine green algae: (a) $\mathrm{Pb}$ (II); (b) $\mathrm{Zn}$ (II); (c) Co(II) $\left(\mathrm{pH}=5.0 ; 8 \mathrm{~g}\right.$ biosorbent $\mathrm{L}^{-1}$, temperature $\left.=22^{\circ} \mathrm{C}\right)$.

In comparison with the pseudo-first order kinetic model, the pseudo-second order kinetic model is based on the assumption that the rate controlling step in the biosorption mechanism is chemical interaction between metal ions and superficial functional groups of biosorbent. The mathematical expression of the pseudo-second order kinetic model can be written in linear form as [31,33]:

$$
\frac{t}{q_{t}}=\frac{1}{k_{2} \cdot q_{e}^{2}}+\frac{t}{q_{e}}
$$

where: $k_{2}$ is the pseudo-second order rate constant $\left(\mathrm{g} \mathrm{mmol}^{-1} \mathrm{~min}^{-1}\right)$.

The intra-particle diffusion model was used to determine the participation of diffusion process in the biosorption of considered heavy metals on untreated and alkaline treated marine green algae. The kinetic equation of intra-particle diffusion model is given by [34]:

$$
q_{t}=k_{\text {diff }} \cdot t^{1 / 2}+c
$$
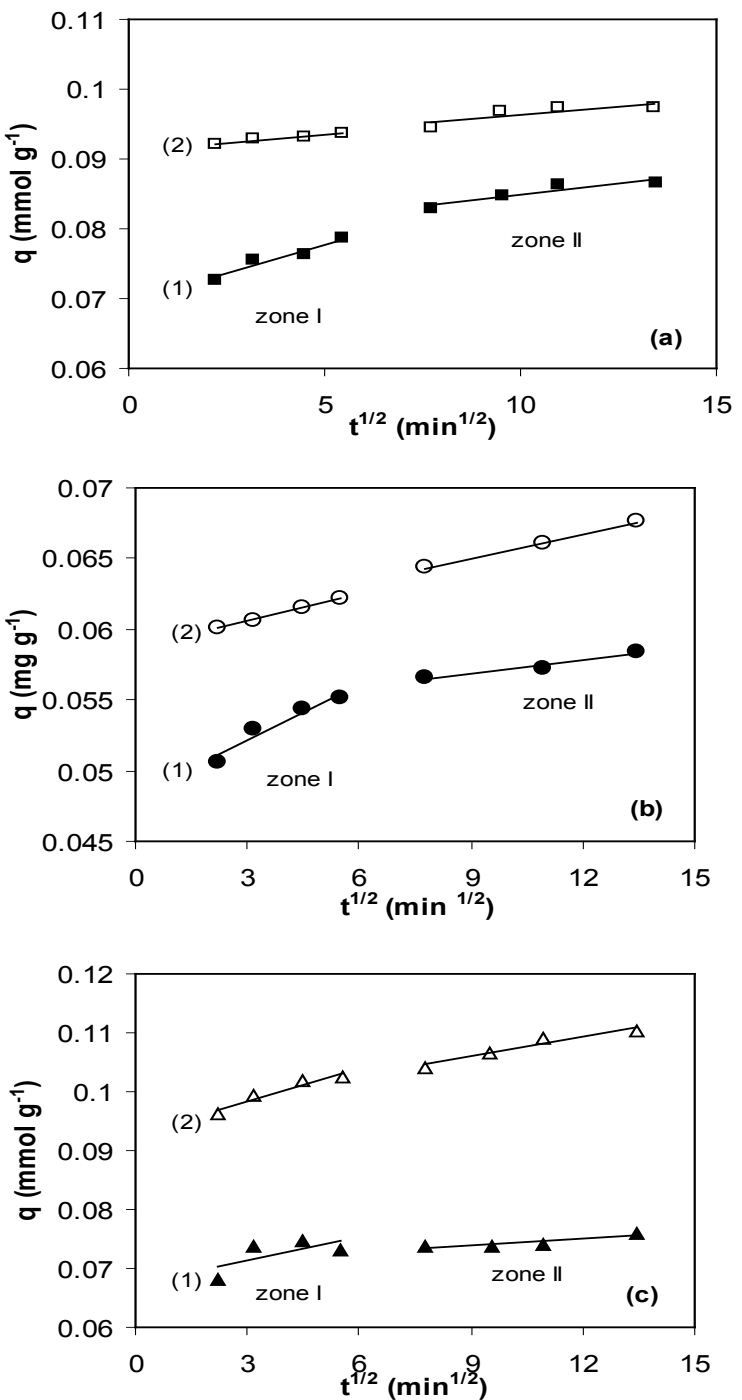

Figure 6: The plots of intra-particle diffusion model for the biosorption of (a) $\mathrm{Pb}$ (II), (b) $\mathrm{Zn}$ (II) and (c) $\mathrm{Co}$ (II) respectively, onto untreated (1) and alkaline treated (2) marine green algae.

where: $k_{\text {diff }}$ is the intra-particle diffusion rate constant $\left(\mathrm{mmol} \mathrm{g}{ }^{-1}\right.$ $\mathrm{min}^{-1 / 2}$ ) and $\mathrm{c}$ is the concentration of heavy metals from solution, at equilibrium $\left(\mathrm{mmol} \mathrm{L}^{-1}\right)$.

The kinetic parameters of the pseudo-first order and pseudo-second order models, calculated from the linear dependences $\lg \left(\mathrm{q}_{\mathrm{e}}-\mathrm{q}_{\mathrm{t}}\right)$ vs. $\mathrm{t}$ and $t / q_{t}$ vs. $t$ respectively, together with the corresponding correlation coefficients $\left(\mathrm{R}^{2}\right)$ are presented in Table 2 .

The obtained results showed that the equilibrium biosorption capacities $\left(\mathrm{q}_{\mathrm{e}}\right.$, mmol $\left.\mathrm{g}^{-1}\right)$ calculated from the pseudo-first order equation is very different from the experimental values $\left(\mathrm{q}_{e} \mathrm{exp}^{\mathrm{e}}, \mathrm{mmol}\right.$ $\left.\mathrm{g}^{-1}\right)$, for all studied heavy metals and both biosorbents. This means that the pseudo-first order kinetic model is not adequate for to describe the kinetics data of $\mathrm{Pb}(\mathrm{II}), \mathrm{Zn}(\mathrm{II})$ and $\mathrm{Co}(\mathrm{II})$ biosorption on untreated and alkaline treated marine green algae.

The experimental data were further fitted by the pseudo-second order kinetic model, and better fitting was obtained with high 


\begin{tabular}{|c|c|c|c|c|c|c|c|}
\hline \multirow{2}{*}{ Isotherm model } & \multirow{2}{*}{ Parameter } & \multicolumn{3}{|c|}{ Untreated marine green algae } & \multicolumn{3}{|c|}{ Alkaline treated marine green algae } \\
\hline & & $\mathrm{Pb}(\mathrm{II})$ & $\mathrm{Zn}(\mathrm{II})$ & Co(II) & $\mathrm{Pb}(\mathrm{II})$ & Zn(II) & Co(II) \\
\hline \multirow{4}{*}{ Langmuir } & $\mathrm{R}^{2}$ & 0.9998 & 0.9991 & 0.9991 & 0.9981 & 0.9957 & 0.9996 \\
\hline & $\mathrm{q}_{\max } \mathrm{mmol} \cdot \mathrm{g}^{-1}$ & 0.4538 & 0.5012 & 0.2406 & 0.6521 & 0.6886 & 0.4675 \\
\hline & $\mathrm{K} L \cdot \mathrm{g}^{-1}$ & 4.4374 & 0.4262 & 0.4371 & 3.5563 & 1.1075 & 0.4734 \\
\hline & $\mathrm{R}_{\mathrm{L}}$ & 0.0623 & 0.4144 & 0.4127 & 0.0765 & 0.2140 & 0.3936 \\
\hline \multirow{3}{*}{ Freundlich } & $\mathrm{R}_{2}$ & 0.9850 & 0.9954 & 0.9702 & 0.9874 & 0.9778 & 0.9893 \\
\hline & $1 / \mathrm{n}$ & 0.7197 & 0.8611 & 0.7692 & 0.6067 & 0.7535 & 0.8007 \\
\hline & $\mathrm{K}_{\mathrm{F}} \mathrm{mmol} \cdot \mathrm{g}^{-1} \cdot\left(\mathrm{L} \cdot \mathrm{mmol}^{-1}\right)^{1 / n}$ & 0.6447 & 0.1523 & 0.0667 & 0.4549 & 0.5436 & 0.1412 \\
\hline \multirow{3}{*}{$\begin{array}{l}\text { Dubinin-Radush- } \\
\text { kevich }\end{array}$} & $\mathrm{R}^{2}$ & 0.9877 & 0.9336 & 0.9478 & 0.9960 & 0.9577 & 0.9562 \\
\hline & $\mathrm{q}_{\max }^{\mathrm{D}-\mathrm{R}} \mathrm{mmol} \cdot \mathrm{g}^{-1}$ & 0.5205 & 0.5632 & 0.2586 & 0.7089 & 0.6916 & 0.4874 \\
\hline & $\mathrm{E} \mathrm{kJ} \cdot \mathrm{mol}^{-1}$ & 12.0712 & 14.1271 & 14.1287 & 11.4549 & 13.9057 & 13.4515 \\
\hline
\end{tabular}

Table 1: Isotherm parameters of the biosorption of $\mathrm{Pb}(\mathrm{II}), \mathrm{Zn}(\mathrm{II})$ and $\mathrm{Co}(\mathrm{II})$ respectively, on untreated and alkaline treated marine green algae (U/va lactuca).

\begin{tabular}{|c|c|c|c|c|c|c|c|c|}
\hline \multirow{2}{*}{ Kinetics model } & \multirow{2}{*}{\multicolumn{2}{|c|}{ Parameter }} & \multicolumn{3}{|c|}{ Untreated marine green algae } & \multicolumn{3}{|c|}{ Alkaline treated marine green algae } \\
\hline & & & $\mathrm{Pb}(\mathrm{II})$ & $\mathrm{Zn}(\mathrm{II})$ & Co(II) & $\mathrm{Pb}(\mathrm{II})$ & $\mathrm{Zn}(\mathrm{II})$ & $\mathrm{Co}(\mathrm{II})$ \\
\hline \multirow{4}{*}{$\begin{array}{l}\text { Pseudo-first order } \\
\text { model }\end{array}$} & \multicolumn{2}{|c|}{$\mathrm{q}_{\exp } \mathrm{mmol} \cdot \mathrm{g}^{-1}$} & 0.0865 & 0.584 & 0.0759 & 0.0974 & 0.0676 & 0.1101 \\
\hline & \multicolumn{2}{|c|}{$\mathrm{R}^{2}$} & 0.9270 & 0.8932 & 0.7774 & 0.8450 & 0.9969 & 0.8933 \\
\hline & \multicolumn{2}{|c|}{$\mathrm{q}_{\mathrm{e}} \mathrm{mmol} \cdot \mathrm{g}^{-1}$} & 0.0193 & 0.0061 & 0.0028 & 0.0690 & 0.0079 & 0.0813 \\
\hline & \multicolumn{2}{|c|}{$\mathrm{k}_{1} \mathrm{~min}^{-1}$} & $6.1244 \cdot 10^{-3}$ & $2.8658 \cdot 10^{-3}$ & $5.2106 \cdot 10-4$ & $4.5158 \cdot 10^{-3}$ & $2.6053 \cdot 10^{-3}$ & $3.9097 \cdot 10^{-4}$ \\
\hline \multirow{3}{*}{$\begin{array}{l}\text { Pseudo-second order } \\
\text { model }\end{array}$} & \multicolumn{2}{|c|}{$\mathrm{R}^{2}$} & 0.9998 & 0.9998 & 0.9996 & 0.9999 & 0.9997 & 0.9996 \\
\hline & \multicolumn{2}{|c|}{$\mathrm{q}_{\mathrm{e}} \mathrm{mmol} \cdot \mathrm{g}^{-1}$} & 0.0875 & 0.0586 & 0.0755 & 0.0978 & 0.0678 & 0.1108 \\
\hline & \multicolumn{2}{|c|}{$\mathrm{k}_{2} \mathrm{~g} \cdot \mathrm{mmol}^{-1} \cdot \mathrm{min}^{-1}$} & 4.7626 & 11.0509 & 14.5476 & 10.6541 & 17.4956 & 16.4462 \\
\hline \multirow{6}{*}{$\begin{array}{c}\text { Intra-particle diffusion } \\
\text { model }\end{array}$} & \multirow{3}{*}{ zone I } & $\mathrm{R}^{2}$ & 0.9445 & 0.9401 & 0.4898 & 0.9431 & 0.9402 & 0.9242 \\
\hline & & c mmol. $\mathrm{L}^{-1}$ & 0.0694 & 0.0539 & 0.0670 & 0.0910 & 0.0481 & 0.0925 \\
\hline & & $\mathrm{k}_{\text {diff }} \mathrm{Immol} \cdot \mathrm{g}^{-1} \cdot \mathrm{min}^{-1}$ & 0.0017 & 0.0003 & 0.0014 & 0.0005 & 0.0013 & 0.0019 \\
\hline & \multirow{3}{*}{ zone II } & $\mathrm{R}^{2}$ & 0.8453 & 0.9977 & 0.7407 & 0.6805 & 0.9971 & 0.9431 \\
\hline & & c mmol. $\mathrm{L}^{-1}$ & 0.0782 & 0.0587 & 0.0704 & 0.0914 & 0.0599 & 0.0960 \\
\hline & & $\mathrm{k}_{\text {diff }} \mathrm{l} \mathrm{mmol} \cdot \mathrm{g}^{-1} \cdot \mathrm{min}^{-1}$ & 0.0007 & 0.0007 & 0.0004 & 0.0005 & 0.0006 & 0.0011 \\
\hline
\end{tabular}

Table 2: Kinetics parameters of the biosorption of $\mathrm{Pb}(\mathrm{II}), \mathrm{Zn}(\mathrm{II})$ and $\mathrm{Co}(\mathrm{II})$ respectively, on untreated and alkaline treated marine green algae (Ulva lactuca).

correlation coefficients $\left(R^{2}>0.9996\right)$, in all cases. More, the values of biosorption capacities calculated from pseudo-second order kinetic model (qe, $\left.\mathrm{mmol} \mathrm{g}^{-1}\right)$ are close to the experimental values $\left(\mathrm{q}_{\mathrm{e}}^{\text {exp }}, \mathrm{mmol} \mathrm{g}^{-1}\right)$, for all studied heavy metals and both biosorbents. These indicate clear that the biosorption of $\mathrm{Pb}$ (II), $\mathrm{Zn}$ (II) and $\mathrm{Co}$ (II) ions on untreated and alkaline treated marine green algae comply with the pseudo-second order kinetic model, which is based on the assumption that the rate controlling step in biosorption mechanism is the chemical interaction, and similar behaviour have been reported for various types of algae used as biosorbents [11,35].

In addition, the higher values of the rate constants obtained in case of alkaline treated marine green algae in comparison with untreated biomass suggests that the rate of biosorption process is limited by the availability of superficial functional groups to interact with metal ions from aqueous solution. When, marine green algae are treated with alkaline solution, some hydrolysis and dissociation processes occur, and these make that the chemical interactions to occur easier. In consequence, the rate of biosorption process increase (as well as the rate constants are higher), than in case of untreated marine green algae.

According to intra-particle diffusion model, if the diffusion process is the rate controlling step in studied systems, the graphical representations of $q_{t} v s . t^{1 / 2}$ should yield a straight line, passing through the origin [34]. However, in this study, the plots $q_{t} v s . t^{1 / 2}$ obtained in case of $\mathrm{Pb}$ (II), $\mathrm{Zn}$ (II) and $\mathrm{Co}(\mathrm{II})$ biosorption on untreated and alkaline treated marine green algae (Figure 6) does not go through the origin, and two separated zones exist in all cases. The parameters of intraparticle diffusion model $\left(\mathrm{k}_{\mathrm{diff}}\right.$ and $\left.\mathrm{c}\right)$ evaluated for each zone, are also presented in Table 2.
The deviation of straight line from the origin indicate that the intraparticle diffusion process is not only rate controlling step [2,34], and the boundary diffusion controls the biosorption up to a certain degree. The first zone (zone I) is attributed to mass transfer of heavy metals from the bulk solution to biosorbent surface $\left(\mathrm{k}_{\text {diff }} \mathrm{I}\right)$, while the second zone (zone II) indicates the intra-particle diffusion $\left(\mathrm{k}_{\mathrm{diff}}\right.$ II). The significant difference between these two zones is given by their slope, when the first zone has a pronounced slope, the slope of second zone is much lower. This indicates that the binding sites are located on biosorbent surface and are readily accessible for the heavy metal ions, or at external intra-layer surface. Hence, the obtained experimental data indicate a limited contribution of mass transfer and boundary layer diffusion in the biosorption process of $\mathrm{Pb}(\mathrm{II}), \mathrm{Zn}(\mathrm{II})$ and $\mathrm{Co}(\mathrm{II})$ respectively, on untreated and alkaline treated marine green algae, and that the intraparticle diffusion influenced the biosorption process up to certain degree.

\section{Desorption and reusability}

In order to make the biosorption process more economical feasible, it is necessary to regenerate the loaded biosorbent. Generally, the regeneration process of loaded biosorbent is performed by desorption, using chemical reagents that must have low cost, highly efficiency and do not damage the structure of biosorbent.

In this study, the desorption of heavy metals (Pb(II), $\mathrm{Zn}(\mathrm{II})$ and $\mathrm{Co}(\mathrm{II})$, respectively) from loaded alkaline treated marine green algae was tested under batch conditions, using different concentrations of aqueous solution of hydrochloric acid. The experimental results have indicate that both studied heavy metals can be readily eluted with 0.1 
Citation: Bulgariu L, Bulgariu D (2014) Enhancing Biosorption Characteristics of Marine Green Algae (Ulva Lactuca) for Heavy Metals Removal by Alkaline Treatment. J Bioprocess Biotech 4: 146 doi: 10.4172/2155-9821.1000146

mol L ${ }^{-1} \mathrm{HCl}$ solution, when $97.5 \%$ of $\mathrm{Pb}(\mathrm{II}), 98.02 \%$ of $\mathrm{Zn}(\mathrm{II})$ and $98.13 \%$ of $\mathrm{Co}(\mathrm{II})$ ions were recovered, for a ratio alkaline treated biosorbent mass:acid volume $=1: 10$. The biosorbent samples, washed with double distilled water and dried in air, were reuse in three biosorption/ desorption cycles, and the loss in the biosorption capacity was less than $3.5 \%$ for $\mathrm{Pb}(\mathrm{II}), 5.7 \%$ for $\mathrm{Zn}(\mathrm{II})$ and $6.2 \%$ for $\mathrm{Co}(\mathrm{II})$, respectively.

\section{Conclusions}

In this study, the biosorptive characteristics of alkaline treated marine green algae (Ulva lactuca) have been investigated for the removal of $\mathrm{Pb}(\mathrm{II}), \mathrm{Zn}$ (II) and $\mathrm{Co}$ (II) ions form aqueous solution, in comparison with untreated biomass. The experiments were examined the effect of $\mathrm{NaOH}$ concentration used form marine green algae treatment, initial heavy metals concentration and contact time, in optimum experimental conditions, at room temperature. The experimental results have indicate that the alkaline treated marine green algae have better biosorption characteristics than untreated biomass, and have potential for serving as biosorbent for removal of heavy metals from aqueous solution.

\section{Acknowledgement}

This work was supported by a grant of the Romanian National Authority for Scientific Research, CNCS-UEFISCDI, project number PN-II-ID-PCE-2011-3-0559.

\section{References}

1. Freitas OMM, Martins RJE, Delerue-Matos CM, Boaventura RAR (2008) Removal of $\mathrm{Cd}(\mathrm{II}), \mathrm{Zn}$ (II) and $\mathrm{Pb}$ (II) from aqueous solutions by brown marine macro algae: Kinetic modelling. J Hazard Mater 153: 493-501.

2. Sulaymon AH, Mohammed AA, Al-Musawi TJ (2013) Removal of lead cadmium, copper, and arsenic ions using biosorption: equilibrium and kinetic studies. Desalination and Water Treatment 51: 4424-4434.

3. Montazer-Rahmati MM, Rabbani P, Abdolali A, Keshtkar AR (2011) Kinetics and equilibrium studies on biosorption of cadmium, lead, and nickel ions from aqueous solutions by intact and chemically modified brown algae. J Hazard Mater 185: 401-407.

4. Mendoza CA, Cortes G, Munoz D (1998) Heavy metal pollution in soils and sediments of rural developing district 063, Mexico. Environ Toxic Water 11: 327-336.

5. Davis TA, Volesky B, Mucci A (2003) A review of the biotechnology of heavy metal biosorption by brown algae. Water Res 37: 4311-4330.

6. Wang J, Chen C (2009) Biosorbents for heavy metals removal and their future Biotechnol Adv 27: 195-226.

7. Llanos J, Williams PM, Cheng S, Rogers D, Wright C, et al. (2010) Characterization of a ceramic ultrafiltration membrane in different operational states after its use in a heavy-metal ion removal process. Water Res 44: 3522 3530.

8. Kumar PS, Ramalingam S, Abhinaya RV, Kirupha SD, Murugesan A, et al. (2012) Adsorption of Metal Ions onto the Chemically Modified Agricultura Waste. CLEAN - Soil, Air, Water 40: 188-197.

9. Mudhoo A, Garg VK, Wang S (2012) Removal of heavy metals by biosorption. Environ Chem Lett 10: 109-117.

10. Arief VO, Trilestari K, Sunarso J, Indraswati N, Ismadji S (2008) Recent Progress on Biosorption of Heavy Metals from Liquids Using Low Cost Biosorbents: Characterization, Biosorption Parameters and Mechanism Studies. CLEAN Soil, Air, Water 36: 937-962

11. Donmez G, Aksu Z, Ozturk A, Kutsal T (1999) A comparative study on heavy metal biosorption characteristics of some algae. Process Biochem 34: 885-892.

12. Feng D, Aldrich C (2004) Adsorption of heavy metals by biomaterials derived from the marine alga Ecklonia maxima. Hydrometallurgy 73: 1-10.

13. Klos A, Rajfur M, Waclawek M, Waclawek W (2005) lon exchange kinetics in lichen environment. Ecol Chem Eng 12: 1353-1365.

14. Hamdy AA (2000) Biosorption of heavy metals by marine algae. Curr Microbio 41: $232-238$

15. Pavasant P, Apiratikul R, Sungkhum V, Suthiparinyanont P, Wattanachira S, et al. (2006) Biosorption of $\mathrm{Cu}^{2+}, \mathrm{Cd}^{2+}, \mathrm{Pb}^{2+}$ and $\mathrm{Zn}^{2+}$ using dried marine green macroalga Caulerpa lentillifera. Bioresource Technol 97: 2321-2329.

16. Deng L, Su Y, Su H, Wang X, Zhu X (2007) Sorption and desorption of lead (II) from wastewater by green algae Cladophora fascicularis. J Hazard Mater 143: 220-225.

17. Kızılkaya B, Dogan F, Akgul R, Turker G (2012) Biosorption of $\mathrm{Co}(\mathrm{II}), \mathrm{Cr}(\mathrm{III})$ $\mathrm{Cd}(\mathrm{II})$, and $\mathrm{Pb}$ (II) Ions from Aqueous Solution Using Nonliving Neochloris Pseudoalveolaris: Equilibrium, Thermodynamic, and Kinetic Study. J Disper Sci Technol 33: 1055-1065.

18. Hu JL, He XW, Wang CR, Li JW, Zhang CH (2012) Cadmium adsorption characteristic of alkali modified sewage sludge. Bioresource Technol 121: 25-30.

19. Karthikeyan S, Balasubramanian R, Iyer CSP (2007) Evaluation of the marine algae Ulva fasciata and Sargassum sp. for the biosorption of $\mathrm{Cu}$ (II) from aqueous solutions. Bioresource Technol 98: 452-455.

20. Lupea M, Bulgariu L, Macoveanu M (2012) Biosorption of Cd(II) from aqueous solution on marine green algae biomass. Environ Eng Manag J 11: 607-615.

21. Dean JA (1995) Analytical Chemistry Handbook. Mc-Grow Hill.

22. Yazici H, Kilic M, Solak M (2008) Biosorption of Copper(II) by Marrubium globosum sub sp. Globosum leaves powder: effect of chemical pretreated. $J$ Hazard Mater 151: 669-675.

23. Chen JP, Yang L (2005) Chemical modification of Sargassum sp. for prevention of organic leaching and enhancement of uptake during metal biosorption. Ind Eng Chem Res 44: 9931-9942.

24. Bulgariu L, Bulgariu D, Macoveanu M (2011) Adsorptive performances of alkaline treated peat for heavy metals removal. Separ Sci Technol 46: 1023 1033

25. Gupta VK, Rastogi A (2008) Biosorption of lead from aqueous solutions by green algae Spirogyra species: kinetics and equilibrium studies. J Hazard Mater 152: 407-414.

26. Fresenius W, Schneider W, Quentin KE (1998) Water Analysis. A Practical Guide to Physico-Chemical and Microbiological Water Examination and Quality Assurance. Springer-Verlag, Berlin, Germany.

27. Chong KH, Volesky B (1995) Description of two-metal biosorption equilibria by Langmuir-type models. Biotechnol Bioeng 47: 451-460.

28. Hameed BH, Ahmad AA, Aziz N (2007) Isotherms, kinetics and thermodynamics of acid dye adsorption on activated palm ash. Chem Eng J 133: 195-203.

29. Lodeiro P, Barriada JL, Herrero R, Sastre de Vicente ME (2006) The marine macroalga Cystoseira baccata as biosorbent for cadmium(II) and lead(II) removal: Kinetic and equilibrium studies. Environ Pollut 142: 264-273.

30. Sari A, Tuzen M (2008) Biosorption of cadmium(II) from aqueous solution by red algae (Ceramium virgatum): Equilibrium, kinetic and thermodynamic studies. J Hazard Mater 157: 448-454

31. Gerente C, Lee VKC, Lee P, McKay G (2007) Application of chitosan for the removal of metals from wastewaters by adsorption - mechanisms and models review. Crit Rev Env Sci Tech 37: 41-127.

32. Febrianto J, Kosasih AN, Sunarso J, Ju YH, Indrawati N, et al. (2009) Equilibrium and kinetic studies in adsorption of heavy metals using biosorbent A summary of recent studies. J Hazard Mater 162: 616-645.

33. Ho YS, Porter JF, McKay G (2002) Equilibrium isotherm studies for the sorption of divalent metal ions onto peat: copper, nickel and lead single component systems. Water Air Soil Poll 141: 1-33.

34. Wu Y, Zhang S, Guo X, Huang H (2008) Adsorption of chromium(III) on lignin. Bioresource Technol 99: 7709-7715.

35. Romera E, Gonzalez F, Ballester A, Blazquez ML, Munoz JA (2007) Comparative study of biosorption of heavy metals using different types of algae. Bioresource Technol 98: 3344-3353. 